\title{
Hepatotoxic activity of Campylobacter jejuni
}

\author{
E. KITA, D. OKU, A. HAMURO, F. NISHIKAWA, M. EMOTO, Y. YAGYU, \\ N. KATSUI and S. KASHIBA
}

Department of Bacteriology, Nara Medical University, 840, Shijyocho, Kashihara, Nara, 634, Japan

\begin{abstract}
Summary. Hepatotoxic factor(s) were isolated from whole-cell lysates of Campylobacter jejuni GIFU 8734 and purified by chromatography. A single intravenous injection of $10 \mu \mathrm{g}$ of this factor reproducibly produced hepatitis in mice, as determined by histology and liver function tests. The hepatic lesions were very similar to those evoked by $C$. jejuni infection. Tissue-culture studies with mouse hepatocytes demonstrated that low concentrations of the factor caused release of hepatic enzymes into the medium without appreciable cytolysis. High concentrations of the factor induced cytolysis. These effects were neutralised by antiserum to the factor, but not by antisera to the lipopolysaccharide of $C$. jejuni or to the heat-labile enterotoxin of Escherichia coli. Among 20 clinical isolates of $C$. jejuni, only four evoked hepatitis in mice and produced the hepatotoxic factor.
\end{abstract}

\section{Introduction}

Campylobacter jejuni, a gram-negative spiral bacterium, is a major cause of diarrhoea in man. ${ }^{1,2}$ Enterotoxigenicity is recognised as one of the contributory factors to its virulence. ${ }^{3-5}$ Various clinical and animal studies indicate that the organism can also cause invasive disease. ${ }^{6-8} \mathrm{He}-$ patic involvement, as well as intestinal lesions, has been associated with campylobacter infection..$^{9-11}$ Previously, we have reported that mice developed focal infiltrative necrotic lesions in the liver within 1 or 2 months of oral infection with $C$. jejuni.$^{12}$ The hepatic damage was demonstrated by histology and liver function tests. However, the mechanism by which $C$. jejuni induces hepatitis in mice has not been established.

In the present study, we examined the production of a hepatotoxic factor by clinical isolates of $C$. jejuni.

\section{Materials and methods}

\section{Bacterial strains}

C. jejuni GIFU $8734^{12}$ was used as a reference strain. Strains Nara-3, $-5,-6,-24,-42,-68,-69,-73,-77$ and -79 , KZ-4, $-6,-9,-12$ and -14, MT- 6 and -10 and DK-1 were clinical isolates from adult patients with campylobacter enteritis. Strains MT-7 and -9 were isolated from asymptomatic carriers. Bacteria were grown routinely at $42^{\circ} \mathrm{C}$ for $24 \mathrm{~h}$ on Brucella Agar (Difco) containing horse blood $10 \% \mathrm{v} / \mathrm{v}$ in an anaerobic jar with a Gas-Pak (BBL

Received 26 Jan. 1990; accepted 19 March 1990.
Microbiology Systems) but without catalyst. The bacteria grown on these plates were transferred into the liquid medium described previously ${ }^{12}$ and incubated at $42^{\circ} \mathrm{C}$ for $48 \mathrm{~h}$ in a micro-aerobic atmosphere.

\section{Preparation of the hepatotoxic factor(s)}

Cells cultured in the liquid medium were harvested

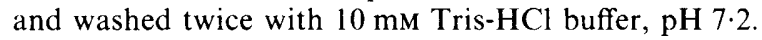
The pellets were resuspended in the same buffer containing $10 \mathrm{mM} \mathrm{MgCl}$, DNAase type I (Sigma) $1 \mathrm{mg} / \mathbf{L}$ and sodium dodecyl sulphate (SDS) $0.05 \% \mathrm{w} / \mathrm{v}$, then disrupted by ultrasonic oscillation (Ultrasonic Oscillator, Kaijyodenki, Tokyo, Japan) for $20 \mathrm{~min}$ at a plate current of $300 \mathrm{~mA}$. The sonicates were centrifuged at $330 \mathrm{~g}$ for $20 \mathrm{~min}$ and the supernates were re-centrifuged at $4200 \mathrm{~g}$ for $60 \mathrm{~min}$. The supernates thus obtained were centrifuged at $12000 \mathrm{~g}$ for $60 \mathrm{~min}$, and then at $90000 \mathrm{~g}$ for $90 \mathrm{~min}$. The final pellet was washed twice with distilled water and lyophilised after dialysis against distilled water. The lyophilised material was dissolved in $10 \mathrm{mM}$ sodium phosphate buffer, $\mathrm{pH} 7 \cdot 2$ (PB), and solid ammonium sulphate was added to $30 \%$ saturation. The mixture was centrifuged at $13000 \mathrm{~g}$ for $30 \mathrm{~min}$ and the pellet, designated P30, was re-dissolved in PB. To the supernate, solid ammonium sulphate was added to $65 \%$ saturation before re-centrifugation at $13000 \mathrm{~g}$ for $30 \mathrm{~min}$. The pellet, designated P65, was suspended in PB. Both P30 and P65 pellets were dialysed for $72 \mathrm{~h}$ at $4{ }^{\circ} \mathrm{C}$ against several changes of distilled water and then lyophilised.

\section{Chromatographic separation of P65}

The lyophilised P65 material was re-dissolved in PB containing $0.05 \mathrm{M} \mathrm{NaCl}$ and applied to a column $(1.6 \times$ $40 \mathrm{~cm}$ ) of Sepharose 4B (Pharmacia Fine Chemicals, 
Uppsala, Sweden) which had been pre-equilibrated with the same buffer. Fractions $(5 \mathrm{ml})$ were collected at a flow rate of $10 \mathrm{ml} / \mathrm{h}$. Those fractions that exhibited cytotoxicity against hepatocytes were pooled and applied to a further column $(2.0 \times 50 \mathrm{~cm})$ packed with DEAE-Sepharose CL-6B (Pharmacia) which had been pre-equilibrated with PB containing $0.05 \mathrm{M} \mathrm{NaCl}$. After the sample was applied, the column was washed with two columnvolumes of the same buffer before elution with $400 \mathrm{ml}$ of $\mathrm{PB}$ containing a gradient $(0.05-0.8 \mathrm{M})$ of $\mathrm{NaCl}$. Fractions $(5 \mathrm{ml})$ were collected at a flow rate of $20 \mathrm{ml} / \mathrm{h}$. Those with hepatotoxic activity were pooled and dialysed overnight at $4^{\circ} \mathrm{C}$ against 100 volumes of Hanks's Balanced Salts Solution (HBSS) without phenol red and then, under identical conditions, against 100 volumes of Williams $E$ Medium (Flow Laboratories, McLean, VA, USA) supplemented with $\mathrm{NaHCO}_{3} 0.07 \%$ w/v, 20 mM HEPES, $2 \mathrm{mM}$ L-glutamine, penicillin, $60 \mathrm{mg} / \mathrm{L}$, streptomycin $50 \mathrm{mg} / \mathrm{L}$ and gentamicin $5 \mathrm{mg} / \mathrm{L}$.

\section{Hepatocyte cultures}

Hepatocytes were isolated from anaesthetised mice by the method of Berry and Friend. ${ }^{13}$ The liver was initially perfused with $50 \mathrm{ml}$ of $\mathrm{Ca}^{2+}$ - and $\mathrm{Mg}^{2+}$-free Hanks's solution (CMFS), then with $100 \mathrm{ml}$ of CMFS containing collagenase (type IV, Sigma) $0.05 \% \mathrm{w} / \mathrm{v}$, bovine serum albumin (BSA, fraction V, Sigma) $0 \cdot 1 \% \mathrm{w} / \mathrm{v}$ and $4 \mathrm{~mm}$ $\mathrm{CaCl}$. All perfusion media were warmed to $37^{\circ} \mathrm{C}$ and gassed with a mixture of $\mathrm{O}_{2} 95 \%$ and $\mathrm{CO}_{2} 5 \%$ for at least $30 \mathrm{~min}$ before use. After the second perfusion, the liver was removed from the animals, rinsed with cold CMFS and placed in a beaker containing $50 \mathrm{ml}$ of cold CMFS. The loose parenchyma was combed free of supporting fibrous tissue, and the cells were dispersed with a spatula. The cell suspensions were filtered through gauze, centrifuged at $50 \mathrm{~g}$ for $5 \mathrm{~min}$ and resuspended in cold HBSS containing fetal calf serum (FCS) $5 \% \mathrm{v} / \mathrm{v}$. The cells were then washed twice with the same solution and finally resuspended in HBSS containing FCS. The number of cells was determined with a haemocytometer and cell viability was determined by the exclusion of trypan blue. Only those preparations containing more than $95 \%$ viable cells were used in tissue culture.

Hepatocytes were suspended to a density of $2 \times$ $10^{6}$ cells $/ \mathrm{ml}$ in Williams E medium supplemented with $10^{-7} \mathrm{M}$ insulin, $10^{-8} \mathrm{M}$ dexamethasone phosphate and FCS $5 \% \mathrm{v} / \mathrm{v}$, and $200-\mu \mathrm{l}$ amounts of these suspensions were seeded into flat-bottomed wells in tissue culture plates (Falcon 3047, Nippon Becton Dickinson Co. Ltd, Tokyo, Japan) which had been coated with collagen (type I, Nitta Gelatine Co., Osaka, Japan) and to which $300 \mu \mathrm{l}$ of the medium was added. After incubation for $2 \mathrm{~h}$ at $37^{\circ} \mathrm{C}$ in $\mathrm{CO}_{2} 5 \%$, unattached cells were removed and fresh medium $(1 \mathrm{ml})$ was added. After $24 \mathrm{~h}$, the culture medium was discarded and fresh medium $(500 \mu \mathrm{l})$ was added. Experiments were started after a further 24-h culture period. At this stage, the culture medium was discarded and fresh medium $(450 \mu \mathrm{l})$ was added to each well. Thereafter, $50 \mu 1$ of HBSS (control sample) or of serial dilutions of the test material were added to the wells and the plates were incubated at $37^{\circ} \mathrm{C}$ in $\mathrm{CO}_{2} 5 \%$.

\section{Determination of viable cell number}

After a 24-h culture period, the hepatocyte monolayers were washed twice with CMFS and the cells were detached by adding a solution of trypsin $0.1 \% \mathrm{w} / \mathrm{v}$ with EDTA $0.02 \% \mathrm{w} / \mathrm{v}$ in CMFS. The cell suspensions obtained were mixed with an equal volume of fresh medium containing FCS $5 \% \mathrm{v} / \mathrm{v}$. The cells were washed twice and suspended in CMFS. The number of viable cells was determined by measurement of the exclusion of trypan blue in a haemocytometer.

\section{Quantification of albumin and excreted enzymes}

The amount of mouse albumin secreted into the medium was measured by rocket immuno-electrophoresis. ${ }^{14}$ Briefly, antiserum $(100 \mu$ l) to mouse serum albumin (Organo Teknika Corp. -Cappel Products, Westchester, PA, USA) was mixed at $50^{\circ} \mathrm{C}$ with $10 \mathrm{ml}$ of agarose $1 \% \mathrm{w} / \mathrm{v}$ in Tris-barbital buffer $\mathrm{pH} 8 \cdot 6 .{ }^{14}$ Pooled mouse serum albumin (fraction $\mathrm{V}$ ) was diluted in culture medium and used as a standard. Medium from freshly isolated hepatocytes was included in each gel to serve as a positive control.

Glutamic-oxaloacetic transaminase (EC 2.6.1.1.: GOT), and lactic dehydrogenase (EC 1.1.1.27: LDH) activities were measured in the supernates. GOT was measured by the method of Henley and Pollard ${ }^{15}$ and LDH by the method of Wróblewski and LaDue. ${ }^{16}$ The reactions were started by adding $100 \mu \mathrm{l}$ of the supernate to $1.9 \mathrm{ml}$ of reaction mixture and the change in absorbance at $340 \mathrm{~nm}$ was measured at $25^{\circ} \mathrm{C}$ in a spectrophotometer. Each enzyme activity was expressed in milli-units $(\mathrm{mU}) / \mathrm{ml}$ of supernate; $1 \mathrm{mU}$ was the amount of enzyme that converted $1 \mathrm{M}$ nmol of substrate/ $\min$.

The enzyme activities in the sera of mice were measured with a Hitachi $706 \mathrm{D}$ autoanalyser, as described previously. ${ }^{12}$

\section{Histological studies}

Multiple sections of the liver were examined after the tissues had been embedded in paraffin, sectioned and stained with haematoxylin and eosin by the conventional method. All slides were read by two observers, neither of whom knew the origin of the individual samples.

\section{Neutralisation test}

Lipopolysaccharide (LPS) was extracted from $C$. jejuni GIFU 8734 by the hot phenol-water technique ${ }^{17}$ and purified by the method of Logan and Trust.$^{18}$ Heat-labile enterotoxin (LT) was extracted and purified from a strain of Escherichia coli (kindly provided by $\mathrm{Dr} \mathrm{M}$. Ehara) by the method of Clements and Finkelstein. ${ }^{19}$ Antiserum to 
the LPS of $C$. jejuni was prepared in ddY mice by the method reported previously. ${ }^{20}$ Antiserum to the LT of $E$. coli was also prepared in mice by the method of Svennerholm et al..$^{21}$

To prepare antiserum to the hepatotoxic factor(s), one volume of the sample $(20 \mathrm{mg} / \mathrm{L})$ was treated with an equal volume of aqueous formaldehyde $6 \% \mathrm{v} / \mathrm{v}$ at $4^{\circ} \mathrm{C}$ for 3 days and then dialysed against 1000 volumes of $P B$ for 3 days with repeated changes of buffer. After membrane filtration, the treated sample $(10 \mathrm{mg} / \mathrm{L}$ in a volume of $500 \mu \mathrm{l})$ was emulsified in an equal volume of Freund's incomplete adjuvant. Mice were immunised by subcutaneous injection of $50 \mu \mathrm{l}$ of the material at the base of the tail, four times at 12-day intervals, and antisera were extracted from groups of 10 mice 7 days after the final injection.

In neutralisation tests, $50 \mu \mathrm{l}$ of hepatotoxic factor(s) $(20 \mathrm{mg} / \mathrm{L})$ was mixed with an equal volume of seriallydiluted antiserum and incubated at $37^{\circ} \mathrm{C}$ for $30 \mathrm{~min}$; 50 $\mu \mathrm{l}$ amounts of these mixtures were then added to hepatocyte cultures. Hepatotoxic factor(s) treated with normal mouse serum was used as a positive control. The GOT activity of each undiluted antiserum was measured before use. After $24 \mathrm{~h}$, cytotoxicity to hepatocytes was measured by exclusion of trypan blue, and leakage of GOT into the supernate was measured as described above.

\section{Infection of mice}

To determine the ability of clinical isolates to colonise the murine liver, groups of five mice were infected by introducing $0.1 \mathrm{ml}$ of HBSS containing $10^{6} \mathrm{cfu}$ directly and atraumatically into the stomach. The mice were killed 30 days after infection and their livers were removed aseptically. The numbers of $C$. jejuni cells in the liver and intestine were measured as described previously. ${ }^{12}$

\section{Statistical tests}

Student's $t$-test was used for statistical comparisons.

\section{Results}

\section{Hepatotoxicity of P65 fractions from C. jejuni}

The hepatotoxicity of the P65 fractions prepared from C. jejuni GIFU 8734 and E. coli 271-6 were compared. The P30 fractions from both species lacked hepatotoxicity. An intravenous injection of $\geq 50 \mu \mathrm{g}$ of the $\mathrm{P} 65$ fraction from $C$. jejuni increased serum concentrations of GOT in mice 5 days after injection. Leakage of GOT increased in a dosedependent manner in the dose range $50-200 \mu \mathrm{g}$ of P65 fraction/mouse (fig. 1). In contrast, the P65 fraction from $E$. coli did not increase GOT concentrations, even when doses as high as $200 \mu \mathrm{g} /$ mouse were administered.

Histological study demonstrated that the P65 fraction from $C$. jejuni affected the parenchymal cells and induced patchy necrotic changes by 7 days



Fig. 1. Liver function in mice given the P65 fraction from C. jejuni GIFU $8734(\square)$ or E. coli 271-6 ( $\square$ ) by intravenous injection. Groups of five mice received the doses of P65 material indicated and were bled 5 days after injection. The data were obtained from two separate experiments and are expressed as the mean $( \pm S D)$ for the 10 mice 

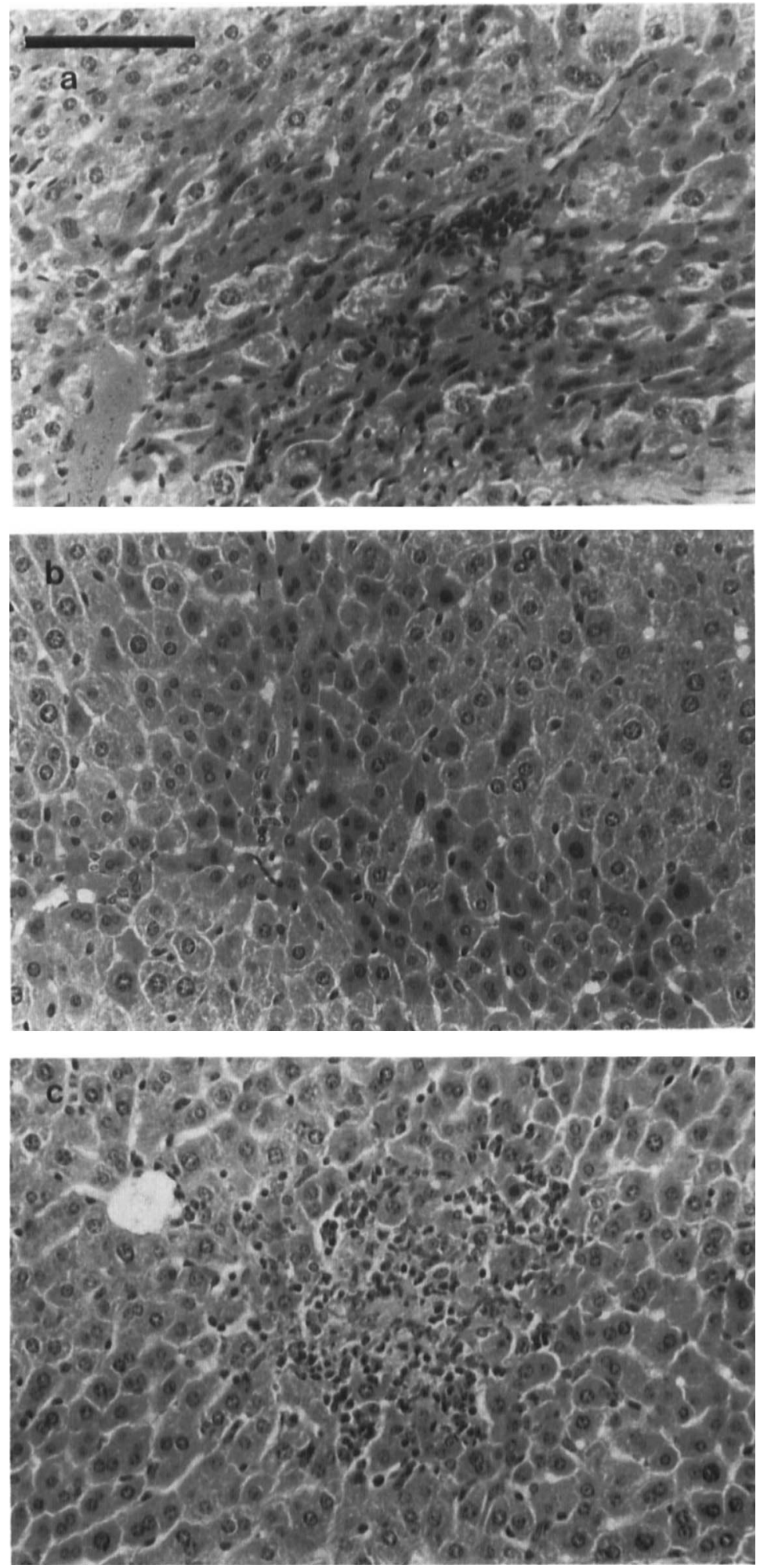

Fig. 2. Histological changes in the liver: (a) 7 days after injection of P65 material from C. jejuni GIFU 8734, $50 \mu \mathrm{g}$ mouse; (b) $48 \mathrm{~h}$ after injection of peak C material, $10 \mu \mathrm{g}$; and (c) 20 days after injection of peak C material, $10 \mu \mathrm{g}$. Bar $=100 \mu \mathrm{m}$. 
after injection (fig. 2a). The P65 fraction of $C$. jejuni also affected cell membranes of hepatocytes as determined by exclusion of trypan blue by cells exposed to doses $>50 \mathrm{mg} / \mathrm{L}$. Its cytotoxic effect increased linearly in the dose range $50-100 \mathrm{mg} / \mathrm{L}$. It was toxic for $58 \%$ of cells at a concentration of $100 \mathrm{mg} / \mathrm{L}$, whereas only $15 \%$ cytotoxicity was obtained with the $\mathrm{P} 65$ fraction from $E$. coli at $100 \mathrm{mg} / \mathrm{L}$ (fig. 3). In the dose range $10-100 \mathrm{mg} / \mathrm{L}$, the P65 fraction from $C$. jejuni enhanced leakage of GOT and LDH, whereas albumin synthesis was reduced by only $20 \%$ at a dose of $100 \mathrm{mg} / \mathrm{L}$ (table I). In contrast, the P65 fraction of $E$. coli induced a slight elevation of GOT and LDH activities in the culture supernates without significant reduction of albumin synthesis.

\section{Chromatographic separation of hepatotoxic factor( $s$ )}

Three peaks were obtained by chromatography of the P65 fraction from C. jejuni on Sepharose 4B (fig. 4a). Hepatotoxicity, as determined by the dye exclusion test, was associated with the second peak. The fractions containing this peak were pooled and subjected to chromatography on DEAE-Sepharose CL-6B. Four peaks, designated A-D, were obtained (fig. 4b). Peak A contained unbound material; peak
B, material eluted with $0.1 \mathrm{M} \mathrm{NaCl}$; peak C, material eluted with $0.3 \mathrm{M} \mathrm{NaCl}$; and peak $\mathrm{D}$, material eluted with $0.5 \mathrm{M} \mathrm{NaCl}$. Only material from peak $\mathrm{C}$, and not that from the other peaks, increased leakage of GOT and LDH from hepatocytes to a significant extent at low dose $(10 \mathrm{mg} / \mathrm{L})$ and caused a marked reduction in synthesis of albumin (table II). Dye exclusion tests demonstrated that material from peak $\mathrm{C}$ caused dosedependent cytotoxic changes in hepatocytes, together with the increased leakage of GOT (fig. 5).

Phase-contrast microscopy showed that hepatocytes incubated for $24 \mathrm{~h}$ with material from peak $\mathrm{C}$, in the concentration range of $1-5 \mathrm{mg} / \mathrm{L}$, showed only a "rounding-up" (fig. 6a). However, higher doses of material from peak C $(>20 \mathrm{mg} / \mathrm{L})$ induced significant cell lysis within $24 \mathrm{~h}$ (fig. 6b), reducing the number of viable cells by $>90 \%$.

\section{Neutralisation tests}

Each antiserum was titrated against glutaraldehyde-treated sheep red-blood cells coated with the corresponding antigen before use by the method described previously. ${ }^{22}$ Haemagglutination titres of all antisera exceeded 128. Pre-treatment of peak $C$ with serial dilutions of antiserum to the LPS of

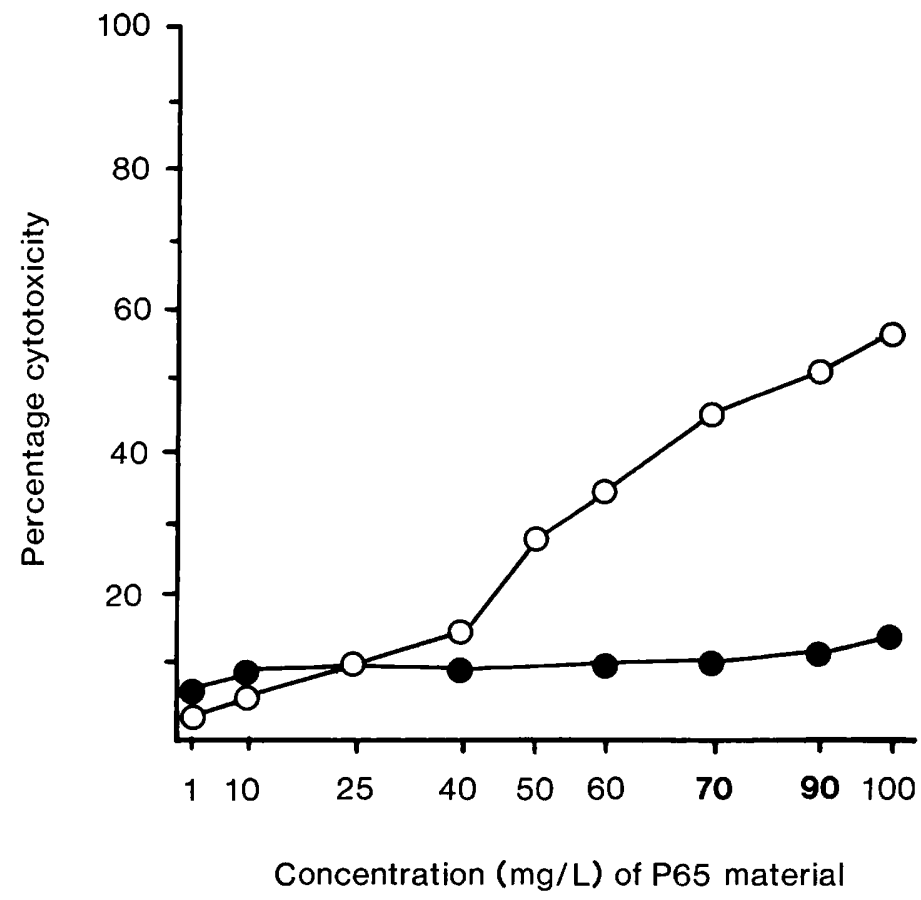

Fig. 3. Toxicity of graded doses of P65 material from C. jejuni GIFU $8734(\bigcirc-\bigcirc)$ or E. coli 271-6 (Ohepatocytes. Cytotoxicity was determined in triplicate cultures after $24 \mathrm{~h}$. The data were obtained from two separate experiments, and are expressed as the means for the six cultures. 
Table I. Effect of P65 preparations on enzyme leakage and albumin synthesis in cultures of mouse hepatocytes

\begin{tabular}{|c|c|c|c|c|}
\hline \multirow[b]{2}{*}{ Sample* } & \multirow{2}{*}{$\begin{array}{c}\text { Concentration } \\
(\mathrm{mg} / \mathrm{L})\end{array}$} & \multicolumn{2}{|c|}{ Released enzymes - mean (SD) $\mathrm{mU} / \mathrm{ml}$} & \multirow{2}{*}{$\begin{array}{l}\text { Albumin synthesis } \\
\text { mean }(\mathrm{SD}) \mathrm{mg} / \mathrm{L}\end{array}$} \\
\hline & & GOT & LDH & \\
\hline Medium control & $\ldots$ & $6(2)$ & $18(6)$ & $2 \cdot 2(0 \cdot 2)$ \\
\hline \multirow[t]{3}{*}{ P65 of $C$. jejuni } & 10 & $14(3)(\mathrm{p}<0 \cdot 1) \dagger$ & $26(7)(\mathrm{p}<0 \cdot 1)$ & $2 \cdot 1(0 \cdot 1)$ \\
\hline & 50 & $24(8)(\mathrm{p}<0.05)$ & $57(0)(\mathrm{p}<0.05)$ & $2 \cdot 0(0 \cdot 1)$ \\
\hline & 100 & $59(7)(\mathrm{p}<0.01)$ & $116(10)(\mathrm{p}<0.01)$ & $1.6(0 \cdot 2)(\mathrm{p}<0 \cdot 1)$ \\
\hline \multirow{2}{*}{ P65 of E. coli } & 50 & $6(3)$ & $19(5)$ & $2 \cdot 2(0 \cdot 2)$ \\
\hline & 100 & $8(2)$ & $20(4)$ & $2 \cdot 1(0 \cdot 1)$ \\
\hline
\end{tabular}

\footnotetext{
*The hepatocytes were cultured with the concentrations of samples indicated for $24 \mathrm{~h}$. Each culture was performed in triplicate and the data were obtained from three different experiments (i.e., nine cultures in total).

$†$ The levels of significance for the observed values compared to the controls.
}

C. jejuni or the LT of E. coli did not abrogate the toxic effects, whereas antiserum to peak $\mathrm{C}$ neutralised its hepatotoxicity (fig. 7).

\section{In-vivo effect of peak $C$}

Intravenous injection of material from peak $\mathrm{C}$ at a dose of $10 \mu \mathrm{g} /$ mouse induced marked elevation of the serum concentrations of GOT and glutamicpyruvic transaminase (EC 2.6.1.2.: GPT) within 2 days (fig. 8). Serum concentrations of GOT and GPT were elevated more rapidly than those of LDH and alkaline phosphatase (EC 3.1.3.1.: ALP), and reached their maxima on the eighth day after injection. In contrast, LDH and ALP increased gradually and reached their maxima between the eighth and twelfth days. Serum concentrations of all four enzymes then fell gradually, but remained significantly elevated even 30 days after injection.
Most of the concentrations remained modestly elevated 3 months after injection.

Histological changes appeared rapidly after injection. The first pathological change was characterised by increased cytoplasmic staining intensity and pyknotic nuclei of hepatocytes (fig. $2 b$ ) and was observed in the parenchyma by $48 \mathrm{~h}$ after injection. Thereafter, the parenchymal changes gradually became localised and the foci of infiltrative lesions became necrotic (fig. 2c) by the twentieth day after injection. These pathological changes were similar to those observed after mice were infected intra-gastrically with living organisms.

\section{Hepatotoxicity of clinical isolates}

Among 20 clinical isolates, 14 persisted in the murine intestine 30 days after intra-gastric inocu-
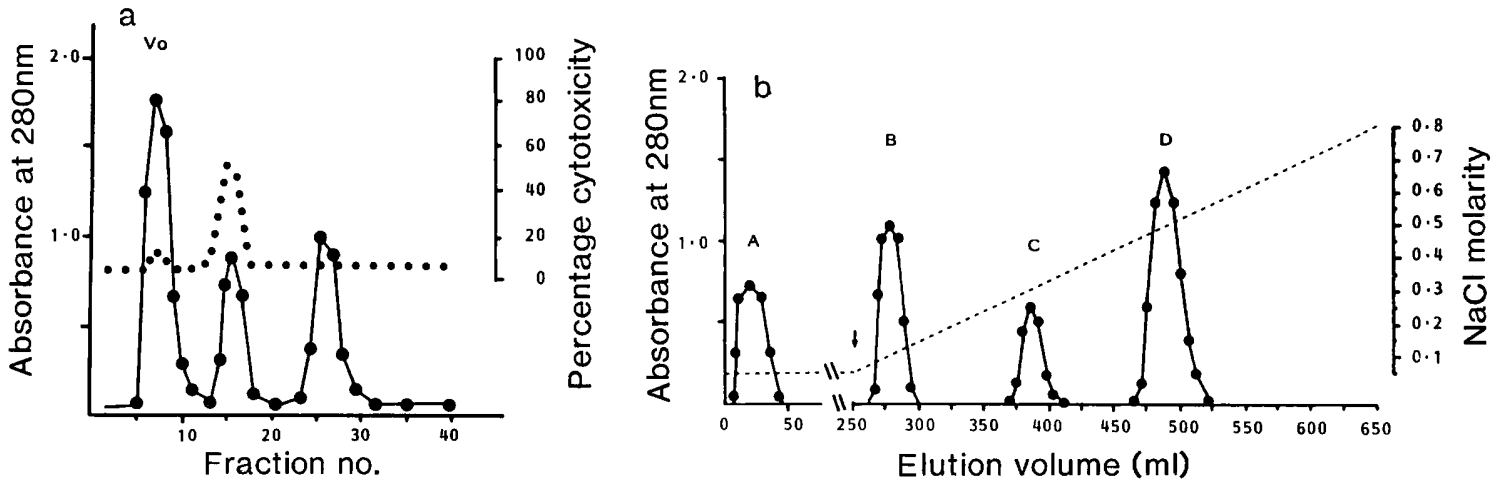

Fig. 4. Chromatographic separation of hepatotoxic factors(s). (a) P65 material from C. jejuni GIFU 8734 chromatographed on Sepharose 4B: - optical density at $280 \mathrm{~nm} ; \cdots \bullet$, percentage cytotoxicity; Vo, void volume. (b) The second peak from Sepharose 4B chromatography was applied to a DEAE-Sepharose 4B column and eluted with an increasing $\mathrm{NaCl}$ gradient (---); $\downarrow$, initiation of gradient elution. 
Table II. Effect of material from peak C on enzyme leakage and albumin synthesis by cultures of mouse hepatocytes

\begin{tabular}{|c|c|c|c|c|}
\hline & & \multicolumn{2}{|c|}{$\begin{array}{l}\text { Enzyme activity released-mean (SD) } \\
\mathrm{mU} / \mathrm{ml}\end{array}$} & \multirow{2}{*}{$\begin{array}{l}\text { Albumin synthesis } \\
\text { mean (SD) } \mathrm{mg} / \mathrm{L}\end{array}$} \\
\hline \multicolumn{2}{|c|}{ Samples } & GOT & LDH & \\
\hline \multicolumn{5}{|l|}{ C. jejuni } \\
\hline P65 & $(10 \mathrm{mg} / \mathrm{L})$ & $15(2)(\mathrm{p}<0 \cdot 1)$ & $27(5)(\mathrm{p}<0 \cdot 1)$ & $2 \cdot 1(0 \cdot 2)$ \\
\hline Peak A & $(10 \mathrm{mg} / \mathrm{L})$ & $7(1)$ & $15(3)$ & $2 \cdot 2(0 \cdot 3)$ \\
\hline Peak B & $(10 \mathrm{mg} / \mathrm{L})$ & $7(2)$ & $17(2)$ & $2 \cdot 1(0 \cdot 1)$ \\
\hline Peak C & $(10 \mathrm{mg} / \mathrm{L})$ & $70(3)(\mathrm{p}<0.01)$ & $164(15)(\mathrm{p}<0.01)$ & $1.2(0.2)(\mathrm{p}<0.05)$ \\
\hline Peak D & $(10 \mathrm{mg} / \mathrm{L})$ & $8(3)$ & $17(3)$ & $2 \cdot 2(0 \cdot 2)$ \\
\hline \multicolumn{2}{|c|}{ Medium control } & $7(1)$ & $16(2)$ & $2 \cdot 3(0 \cdot 2)$ \\
\hline
\end{tabular}

See footnotes to table I.

lation (table III). Only eight of these also colonised the liver, and liver function tests disclosed that only four (Nara 24, KZ-6, MT-7 and DK-13) evoked hepatitis. P65 fractions prepared from the eight strains that colonised the liver were tested for hepatotoxicity in vitro and in vivo. The results are summarised in table IV. Only those fractions obtained from the four strains that caused hepatitis induced significant leakage of GOT and LDH 5 days after animals were given intravenous injections containing $100 \mu \mathrm{g}$ of the P65 preparations.
This capacity correlated well with cytotoxicity, as determined by the dye exclusion test.

\section{Discussion}

These results provide supportive evidence for our earlier view ${ }^{12}$ that $C$. jejuni can induce hepatitis in mice. The hepatotoxicity was attributable to subcellular components. These were enriched in the particulate fraction obtained by a 90 -min centrifugation of lysed bacteria at $90000 \mathrm{~g}$. The chromato-

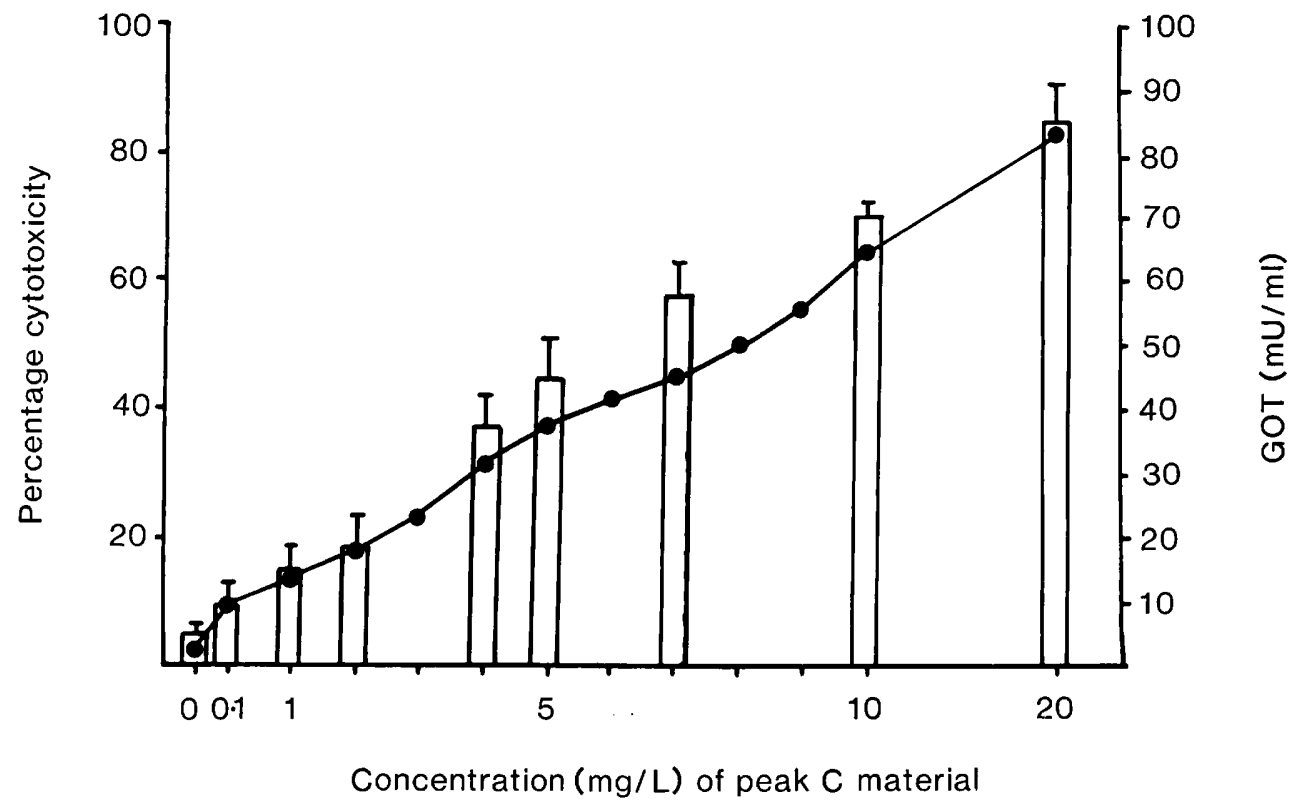

Fig. 5. Toxicity of graded doses of peak C material for mouse hepatocytes. GOT leakage into the supernatant fluid and cytotoxicity for hepatocytes were assayed after $24 \mathrm{~h}$ in triplicate cultures. Data were obtained from three separate experiments, and are expressed as the mean (SD) for the 15 cultures; 



Fig. 6. Effect of peak C material on the morphology of hepatocytes cultured for $24 \mathrm{~h}$ with: (a) peak C material, $5 \mathrm{mg} / \mathrm{L}$; (b) peak C material, $20 \mathrm{mg} / \mathrm{L}$; (c) LPS from C. jejuni GIFU 8734, $5 \mathrm{mg} / \mathrm{L}$. Bar $=100 \mu \mathrm{m}$. 


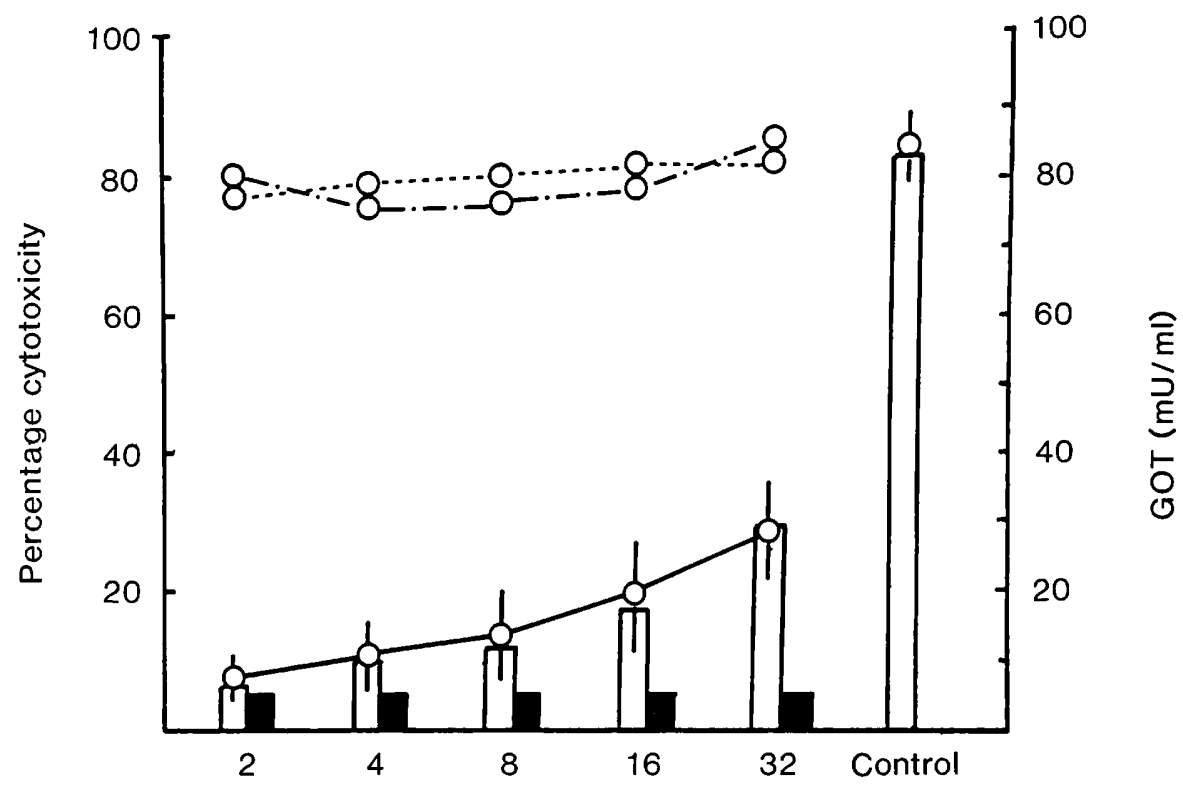

\section{Dilution of antiserum}

Fig. 7. Protective effect of antiserum to peak $\mathrm{C}$ material. GOT leakage and cytotoxicity were assayed in triplicate cultures after $24 \mathrm{~h}$ and the results are expressed as the mean $( \pm S D)$ for the three cultures: cytotoxicity for mouse hepatocytes cultured with peak $C$ material $(10 \mathrm{mg} / \mathrm{L})$ treated with an equal volume of serially diluted homologous antiserum $(O-O)$, antiserum to $C$. jejuni LPS $\left(\mathrm{O}^{--} \mathrm{O}\right)$, or antiserum to LT from $E$. coli 271-6(O- - $\left.\mathrm{O}\right)$; GOT leakage from hepatocytes treated with $\mathrm{C}$ material plus homologous antiserum $(\square)$, or with normal mouse serum (control) $(\square)$.
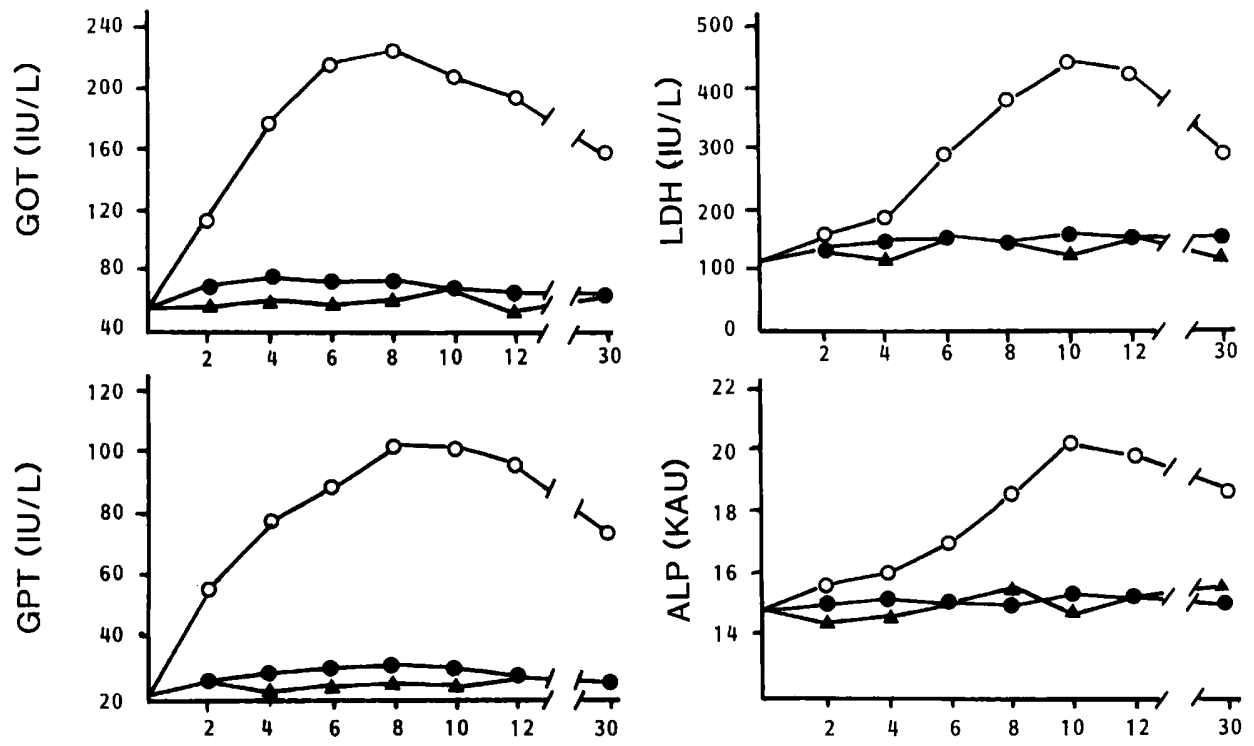

Days after injection

Days after injection

Fig. 8. Liver function tests in mice given $10 \mu \mathrm{g}$ of peak $\mathrm{C}$ material by intravenous injection. Three mice were examined per group at each time point and the results are expressed as the means of three samples. GOT, GPT and LDH are expressed in IU/L and ALP in KAU for mice given peak C material, $10 \mu \mathrm{g}(\mathrm{O})$, mice given LPS from $C$. jejuni GIFU 8734, $10 \mu \mathrm{g}()_{)}$, and mice given PB as controls $(\mathbf{A})$. 
graphically-purified toxic factor (peak C) exhibited hepatotoxicity both in vivo and in vitro. A single intravenous injection of material from peak $\mathrm{C}$ at doses as low as $10 \mu \mathrm{g} /$ mouse evoked hepatitis, as determined by liver function tests and histological studies. Material from peak $\mathrm{C}$ produced a focal infiltrative necrosis in the parenchyma, giving lesions that were very similar to those evoked in the livers of mice by intra-gastric administration of live bacteria.

Addition of material from peak $\mathrm{C}$ to hepatocyte cultures resulted in a significant, dose-dependent, increase in the leakage of GOT and LDH. Dye exclusion tests demonstrated that the severity of cytotoxicity correlated with the degree of enzyme leakage. Hepatocytes cultured with material from peak $\mathrm{C}$ at concentrations below $5 \mathrm{mg} / \mathrm{L}$ showed only a "rounding-up" during a 24-h culture. As the concentration of peak $\mathrm{C}$ material was increased, the rounded-up cells detached from plates and, finally, areas of cytolysis were observed in the monolayers. It is known that detachment of the cells in the culture dishes occurs as a very early event in hepatocyte damage during culture. ${ }^{23}$ The fact that peak $\mathrm{C}$ material induced an increase in leakage of GOT from hepatocytes at doses ( $1-5 \mathrm{mg}$ / L) below those causing cell detachment suggests that the leakage may reflect changes in membrane permeability, not cell rupture. Higher concentrations of peak C material $(>20 \mathrm{mg} / \mathrm{L})$ induced marked leakage of GOT and also cytolysis. Here, enzyme leakage was due not only to permeabilisation of the cell membranes but also to rupture of the hepatocytes. Although it is known that enzyme leakage increases as a result of change in cell permeability ${ }^{24-26}$ the mechanisms of liver damage induced by the peak $\mathrm{C}$ material remains to be studied.

As previously reported, ${ }^{12}$ some strains of $C$. jejuni can persist in the liver and gall bladder for a long period after intra-gastric inoculation. Organisms that have colonised the hepatobiliary tract can continue to release hepatotoxic factor(s). Since intra-gastric administration of peak $\mathrm{C}$ material did not induce hepatitis (data not shown), the factor may be released only from bacteria capable of colonising the hepatobiliary tract.

Twenty clinical isolates of $C$. jejuni were tested

Table III. Source details and pathogenicity of 20 clinical isolates of $C$. jejuni

\begin{tabular}{|c|c|c|c|c|c|}
\hline \multirow[b]{2}{*}{ Strain } & \multicolumn{2}{|c|}{ Clinical manifestation } & \multicolumn{3}{|c|}{ Pathogenicity in mice* } \\
\hline & Stool & Fever & $\begin{array}{l}\text { Intestinal† } \\
\text { colonisation }\end{array}$ & $\begin{array}{c}\text { Liver } \ddagger \\
\text { colonisation }\end{array}$ & Hepatitis $\S$ \\
\hline GIFU 8734 & \multicolumn{2}{|c|}{ Reference strain } & + & + & + \\
\hline Nara-3 & Watery & + & + & - & - \\
\hline Nara-5 & Watery & + & - & - & - \\
\hline Nara-6 & Watery & - & + & - & - \\
\hline Nara-24 & Bloody & + & + & + & + \\
\hline Nara-42 & Watery & - & - & - & - \\
\hline Nara-68 & Watery & + & - & - & - \\
\hline Nara-69 & Bloody & + & + & + & - \\
\hline Nara-73 & Bloody & - & + & - & - \\
\hline Nara-77 & Watery & + & + & - & - \\
\hline Nara-79 & Watery & - & + & - & - \\
\hline $\mathrm{KZ}-4$ & Watery & - & - & - & - \\
\hline $\mathrm{KZ}-6$ & Watery & - & + & + & + \\
\hline $\mathrm{KZ}-9$ & Watery & + & + & + & - \\
\hline $\mathrm{KZ}-12$ & Bloody & + & + & + & - \\
\hline $\mathrm{KZ}-14$ & Watery & - & + & - & - \\
\hline MT-6 & Watery & + & - & - & - \\
\hline MT-7 & \multicolumn{2}{|c|}{ Asymptomatic } & + & + & + \\
\hline MT-9 & \multicolumn{2}{|c|}{ Asymptomatic } & + & + & - \\
\hline MT-10 & Watery & - & - & - & - \\
\hline DK-13 & Bloody & + & + & + & + \\
\hline
\end{tabular}

${ }^{*}$ Groups of five mice were infected intra-gastrically with $10^{6} \mathrm{cfu}$ and bled 30 days after infection.

$\dagger+$, More than four mice were found to carry $1000 \mathrm{cfu} / \mathrm{g}$ of intestinal tissue.

$\ddagger+$, More than four mice were found to carry $1000 \mathrm{cfu} / \mathrm{g}$ of liver tissue.

$\S+$, More than four mice exhibited serum GOT activities $>100 \mathrm{IU} / \mathrm{L}$. 
Table IV. Comparison of hepatotoxicity of P65 fractions prepared from eight strains of $C$. jejuni capable of colonising the mouse liver

\begin{tabular}{|c|c|c|c|}
\hline \multirow[b]{2}{*}{ Strain* } & \multicolumn{2}{|c|}{$\begin{array}{l}\text { Serum enzymes- } \\
\text { mean (SD) IU/L } \dagger\end{array}$} & \multirow{2}{*}{$\begin{array}{c}\text { Percentage } \\
\text { cytotoxicity } \ddagger- \\
\text { mean (SD) }\end{array}$} \\
\hline & GOT & LDH & \\
\hline GIFU 8734 & $158(22)$ & $394(46)$ & $58 \cdot 4(6 \cdot 2)$ \\
\hline Nara-24 & $142(16)$ & $400(33)$ & $56 \cdot 5(5 \cdot 3)$ \\
\hline Nara-69 & $60(13)$ & $128(19)$ & $9 \cdot 8(2 \cdot 2)$ \\
\hline KZ-6 & $162(31)$ & $402(36)$ & $60 \cdot 3(2 \cdot 2)$ \\
\hline KZ-9 & $62(15)$ & $131(20)$ & $10 \cdot 2(3 \cdot 6)$ \\
\hline $\mathrm{KZ}-12$ & $58(9)$ & $126(18)$ & $9 \cdot 8(3.4)$ \\
\hline MT-7 & $155(18)$ & $379(26)$ & $57 \cdot 8(4 \cdot 2)$ \\
\hline MT-9 & $56(11)$ & $125(42)$ & $8 \cdot 6(2 \cdot 5)$ \\
\hline DK-13 & $212(32)$ & $416(42)$ & $67 \cdot 7(5 \cdot 9)$ \\
\hline
\end{tabular}

\begin{abstract}
*Groups of five mice were given $100 \mu \mathrm{g}$ of the P65 fractions from each strain by intravenous injection.

† Mice were bled 5 days after injection and the serum concentrations of GOT and LDH were measured; the experiment was done twice. Control GOT and LDH activities were 52 (11) IU/L and 110 (14) IU/L, respectively.

†Cytotoxicity was assayed by the exclusion of trypan blue in a 24 h-culture of mouse hepatocytes dosed with P65 material $75 \mathrm{mg} / \mathrm{L}$. Seven cultures were treated with each strains. Control samples (HBSS) caused $5 \cdot 6(2 \cdot 2) \%$ cytotoxicity.
\end{abstract}

for hepatotoxicity. Those strains that could colonise the liver did not always induce hepatocellular damage. However, strains capable of inducing liver damage could always colonise the liver. Hepatotoxic strains were isolated from asymptomatic patients.

\section{REFERENCES}

1. Blaser MJ, Reller BL. Campylobacter enteritis. $N$ Engl J Med 1981; 305: 1444-1452.

2. Walker RI, Caldwell MB, Lee EC, Guerry P, Trust TJ, Ruiz-Palacios GM. Pathophysiology of Campylobacter enteritis. Microbiol Rev 1986; 50: 81-94.

3. Ruiz-Palacios GM, Torres J, Torres NI, Escamilla E. Cholera-like enterotoxin produced by Campylobacter jejuni. Lancet 1983; 2: 250-252.

4. Blaser MW, Berkowitz ID, LaForce FM, Cravens J, Reller LB, Wang W-LL. Campylobacter enteritis: clinical and epidemiologic features. Ann Int Med 1979; 91: 179-185.

5. Klipstein FA, Engert RF. Properties of crude Campylobacter jejuni heat-labile enterotoxin. Infect Immun 1984; 45 : 314-319.

6. Lambert ME, Schofield, PF, Ironside, AG, Mandel BK. Campylobacter colitis. Br Med J 1979; 1 : 857-859.

7. Ruiz-Palacios GM, Escamilla E, Torres N. Experimental Campylobacter diarrhea in chickens. Infect Immun $1981 ; 34: 250-255$.

8. Caldwell MB, Walker RI, Stewart SD, Rogers JE. Simple
It has not yet been ascertained whether the hepatotoxic factor is involved in the pathogenesis of campylobacter enteritis. However, it was found that material from peak $\mathrm{C}$ did not induce morphological changes in $\mathrm{CHO}$ and $\mathrm{Y} 1$ cells in preliminary experiments. Additionally, neither antiserum to the LPS of $C$. jejuni nor antiserum to the LT of E. coli neutralised the hepatotoxicity of peak $C$. These results indicate that the hepatotoxic factor(s) in peak $C$ are different from the LPS of $C$. jejuni and from LT. Moreover, only antiserum to peak C material could prevent both the enzyme leakage from cultured hepatocytes and the morphological changes induced in hepatocytes by peak $C$.

$C$. jejuni has been recognised only as an enteropathogenic organism; however, several investigators have reported hepatitis following campylobacter enteritis. ${ }^{10,11}$ Nonetheless, only $20 \%$ of the strains examined here exhibited hepatotoxicity in mice. Preliminary experiments demonstrated that the hepatotoxic activity of peak $\mathrm{C}$ material was impaired by heating at $60^{\circ} \mathrm{C}$ for $30 \mathrm{~min}$ and by digestion with trypsin. Studies are now in progress to further purify peak $\mathrm{C}$ material to allow characterisation of the active component and its physico-chemical properties, and also be ascertain whether this factor can be involved in hepatitis associated with $C$. jejuni infections in man.

This work was supported in part by the Yakult Foundation for Research for Enteric Infections. We thank M. Ehara for providing LT-producing strain $E$. coli 271-6. The authors greatly appreciate the assistance of I. Tanikawa in the preparation of this manuscript.

adult rabbit model for Campylobacter jejuni enteritis. Infect Immun 1983; 42: 1176-1182.

9. Ampelas M, Perz C, Jourdan J, Nalet B, Raynaud A, Emberger JM, Michel $\mathrm{H}$. Hépatite à Campylobacter coli. Nouv Press Méd 1982; 11 : 593-595.

10. Reddy KR, Thomas E. Campylobacter jejuni enterocolitis and hepatitis. Gastroenterology 1982; 82: 1156.

11. Pitkänen T, Pönkä A, Pettersson R, Kosunen TU. Campylobacter enteritis in 188 hospitalized patients. Arch Intern Med 1983; 143: 215-219.

12. Kita E, Katsui N, Nishi K, Emoto M, Yanagase $Y$, Kashiba S. Hepatic lesions in experimental Campylobacter jejuni infection of mice. J Gen Microbiol 1986; 132: 30953103.

13. Berry MN, Friend DS. High-yield preparation of isolated rat liver parenchymal cells. A biochemical and fine structural study. J Cell Biol 1969; 43: 506-520.

14. Weeke B. A manual of quantitative immunoelectrophoresis. Methods and applications. 1. General remarks on principles, equipment, reagents and procedures. Scand J Immunol Suppl 1973; 1: 15-35.

15. Henley KS, Pollard HM. A new method for determination of glutamic oxaloacetic and glutamic pyruvic transam- 
inase in plasma. $J$ Lab Clin Med 1955 ; 46 : 785-789.

16. Wróblewski F, LaDue JS. Lactic dehydrogenase activity in blood. Proc Soc Exp Biol Med 1955; 90 : 210-213.

17. Westphal O, Jann K. Bacterial lipopolysaccharides: extraction with phenol-water and further applications of the procedure. Methods Carbohydr Chem 1965; 5: 83-91.

18. Logan SM, Trust TJ. Structural and antigenic heterogeneity of lipopolysaccharides of Campylobacter jejuni and Campylobacter coli. Infect Immun 1984; 45: 210-216.

19. Clements JD, Finkelstein RA. Immunological cross-reactivity between a heat-labile enterotoxin(s) of Escherichia coli and subunits of Vibrio cholerae enterotoxin. Infect Immun 1978; 21 : 1036-1039.

20. Kita $E$, Kashiba $S$. Immunogenicity of the ribosomal fraction of Salmonella typhimurium: Analysis of humoral immunity. Infect Immun 1980; 27 : 197-203.

21. Svennerholm A-M, Lange S, Holmgren J. Correlation between intestinal synthesis of specific immunoglobulin
A and protection against experimental cholera in mice. Infect Immun 1978; 21 : 1-6.

22. Kita E, Matsuura H, Masuda S, Tomihata S, Kashiba S. Immunogenic dialyzable factor derived from a ribosomal fraction of Salmonella typhimurium. I. Preparation of the protective dialyzable factor from the ribosomal fraction by the freeze-thaw procedure. Microbiol Immunol 1983; 27: 7-24.

23. Laishes BA, Williams GM. Conditions affecting primary cell cultures of functional adult rat hepatocytes. II. Dexamethasone enhanced longevity and maintenance of morphology. In Vitro $1976 ; 12: 821-832$.

24. Sweetin JC, Thomson WHS. Enzyme efflux and clearance. Clin Chem Acta 1973; 48: 403-411.

25. Wilkinson JH, Robinson JM. Effect of ATP on release of intra-cellular enzymes from damaged cells. Nature $1974 ; 249: 662-663$.

26. Shell WE, Sobel BE. Biochemical markers of ischemic injury. Circulation 1976; 53 Suppl 1: 98-106. 